\title{
SUPLEMENTASI GAMAL SEBAGAI RUMEN DEGRADABLE PROTEIN (RDP) UNTUK MENINGKATKAN KECERNAAN (IN VITRO) RANSUM TERNAK RUMINANSIA YANG MENGANDUNG JERAMI PADI
}

\author{
NI NYOMAN SURYANI, I KETUT MANGKU BUDIASA DAN I PUTU ARI ASTAWA \\ FAKULTAS PETERNAKAN UNIVERSITAS UDAYANA DENPASAR BALI \\ email: mansuryani@yahoo.com
}

\begin{abstract}
ABSTRAK
Penelitian ini bertujuan untuk mengetahui kecernaan fermentatif bahan kering (KCFBK) dan bahan organik (KCFBO) serta hasil fermentasi ransum yang mengandung jerami padi dan disuplementasi dengan gamal sebagai RDP secara in vitro. Empat perlakuan ransum disusun berdasarkan BK adalah: (A) rumput gajah 45\%+jerami padi o\%+gamal 15\%+kaliandra 10\%+konsentrat 30\%; (B) rumput gajah 30\%+jerami padi 10\%+gamal 20\%+kaliandra 10\%+konsentrat 30\%; (C) rumput gajah $15 \%+$ jerami padi $20 \%+$ gamal $25 \%+$ kaliandra $10 \%+$ konsentrat $30 \%$, dan (D) rumput gajah o\%+jerami padi 30\%+gamal 30\%+kaliandra 10\%+ konsentrat 30\%. Fermentasi ransum secara in vitro pada pengamatan 4 dan 48 jam menggunakan metode Minson \& Mc Leod Method (1972) yang dimodifikasi. Hasil penelitian menunjukkan, pada fermentasi ransum secara in vitro baik pada inkubasi 4 jam maupun 48 jam, $\mathrm{pH}$ substrat ransum tetap berada dalam kisaran normal $(6,54-, 79)$. Meningkatnya jumlah gamal sebagai RDP dalam ransum meningkatkan konsentrasi $\mathrm{N}-\mathrm{NH}_{3}, \mathrm{KCFBK}$ dan KCFBO. Konsentrasi N-NH${ }_{3}, \mathrm{KCFBK}$ dan KCFBO meningkat pada inkubasi 48 jam dibandingkan inkubasi 4 jam. Berdasarkan hasil penelitian tersebut dapat disimpulkan bahwa potensi jerami padi sebagai komponen ransum ternak ruminansia terbaik ditunjukkan oleh perlakuan $\mathrm{C}$ dibanding semua perlakuan berdasarkan degradabilitas dan kecernaan BK dan BO ransum.
\end{abstract}

Kata kunci: komposisi hijauan, kecernaan fermentatif in vitro, $\mathrm{N}-\mathrm{NH}_{3}$, VFA Total

\section{SUPLEMENTATION OF GLYRICIDIA AS RUMEN DEGRADABLE PROTEIN (RDP) TO IMPROVE DIGESTIBILITY (IN VITRO) OF RUMINANT RATION CONTAINING RICE STRAW}

\begin{abstract}
This study aims to determine the dry matter and organic matter digestibility and result of fermentation in vitro in rations containing rice straw supplemented by glyricidia as Rumen Degradable Protein (RDP). Four rations treatment based on DM were: (A) $45 \%$ elephant grass $+0 \%$ rice straw $+15 \%$ glyricidia $+10 \%$ calliandra $+30 \%$ concentrate; (B) $30 \%$ elephant grass $+10 \%$ rice straw $+20 \%$ glyricidia $+10 \%$ calliandra $+30 \%$ concentrate; (C) $15 \%$ elephant grass $+20 \%$ rice straw $+25 \%$ glyricidia $+10 \%$ calliandra $+30 \%$ concentrate, and (D) $0 \%$ elephant grass $+30 \%$ rice straw $+30 \%$ glyricidia $+10 \%$ calliandra $+30 \%$ concentrate. Ration fermented in vitro at 4 and 48 hours of observations using modified Minson \& Mc Leod Method (1972). The results showed, the ration fermentation in vitro incubation either at 4 hours and 48 hours, the $\mathrm{pH}$ of the substrate ration remained within the normal range (6.54 to 6.79). The increasing number of glyricidia as RDP in the ration increased the concentration of $\mathrm{N}^{-\mathrm{NH}} 3$, dry matter and organic matter digestibility. The concentration of $\mathrm{N}-\mathrm{NH} 3$, and dry matter and organic matter digestibility increased in an incubation of 48 hours compared to 4 hours incubation. Based on these results it can be concluded that the potential components of rice straw as ruminant rations best demonstrated by treatment $\mathrm{C}$ than all treatments based on degradability and digestibility of DM and OM rations.
\end{abstract}

Keywords: forage composition, in vitro digestibility, $\mathrm{N}-\mathrm{NH}_{3}$, Total VFA

\section{PENDAHULUAN}

Penggunaan jerami padi sebagai sumber pakan serat tunggal sering tidak memenuhi kecukupan nutrien. Hal ini disebabkan karena jerami padi yang merupakan limbah pertanian mempunyai nilai nutrisi terutama kandungan protein kasar dan kecernaan yang rendah serta bersifat bulky. Faktor penghambat utama dalam 
penggunaan jerami padi sebagai makanan ternak adalah rendahnya koefisien cerna dan nilai gizi bahan tersebut. Rendahnya koefisien cerna jerami padi karena availabilitas karbohidrat dari serat kasarnya adalah rendah. Hal ini disebabkan karena terbentuknya ikatan kimia antara polimer komplek lignoselulose dengan ikatan intermolekuler, terjadinya kristalinitas dari pada lignin dan silika (Friss, 1982).

Untuk mengatasi kendala ini maka pemanfaatan jerami padi perlu diimbangi dengan hijauan lokal sebagai sumber protein yang larut di dalam rumen yaitu gamal. Penambahan gamal pada pakan yang menggunakan jerami padi bertujuan untuk memberikan sumber nitrogen bagi kehidupan mikroorganisme rumen. Karena ternak ruminansia sangat tergantung kepada mikroorganisme rumen untuk mensuplai enzim yang mampu mencerna serat kasar dalam jerami padi (Schiere dan Ibrahim, 1989).

Untuk membantu mikroorganisme rumen mencerna jerami padi, berbagai usaha telah dilakukan sebelum jerami padi diberikan kepada ternak antara lain perlakuan pisik, khemis dan penambahan berbagai feed aditif, suplementasi multivitamin dan mineral. Untuk memaksimalkan pemanfaatan jerami padi sebagai sumber serat, maka berbagai hijauan lain perlu ditambahkan. Misalnya hijauan gamal yang berfungsi sebagai sumber protein yang mudah terdegradasi di dalam rumen. Degradasi protein gamal akan menghasilkan $\mathrm{N}^{-\mathrm{NH}_{3}}$ yang sangat dibutuhkan oleh mikroorganisme rumen untuk mensintesis protein tubuhnya. Dengan demikian diharapkan populasi maupun aktivitas mikroorganisme rumen meningkat sehingga kecernaan pakan yang mengandung jerami padi juga meningkat yang pada akhirnya mampu meningkatkan pertumbuhan dan pertambahan bobot badan ternak ruminansia.

Penelitian ini bertujuan untuk mengetahui kecernaan Bahan Kering (BK) dan Bahan Organik (BO) serta hasil fermentasi ransum yang mengandung jerami padi dan disuplementasi dengan gamal sebagai RDP secara in vitro.

\section{METODE PENELITIAN}

\section{Ransum Perlakuan}

Ransum perlakuan dibuat sebagai pakan komplit dalam bentuk mash terdiri dari hijauan dan konsentrat. Komposisi ransum disajikan pada Tabel 1, komposisi konsentrat pada Tabel 2

\section{Fermentasi In Vitro}

In vitro dilakukan pada dua waktu inkubasi yaitu 4 jam dan 48 jam. Metode yang digunakan adalah Minson \& Mc Leod Method (1972) yang dimodifikasi. Cara kerja untuk penelitian in vitro yaitu: sampel ransum yang telah halus dimasukkan ke dalam tabung in vitro
Tabel 1. Komposisi Ransum Perlakuan

\begin{tabular}{lcccc}
\hline \multirow{2}{*}{$\begin{array}{c}\text { Bahan Penyusun Ransum } \\
\text { (\% BK) }\end{array}$} & \multicolumn{4}{c}{ Perlakuan } \\
\cline { 2 - 5 } & $\mathrm{A}$ & $\mathrm{B}$ & $\mathrm{C}$ & $\mathrm{D}$ \\
\hline Rumput Gajah & 45,00 & 30,00 & 15,00 & 0,00 \\
Jerami padi & 0,00 & 10,00 & 20,00 & 30,00 \\
Gamal & 15,00 & 20,00 & 25,00 & 30,00 \\
Kaliandra & 10,00 & 10,00 & 10,00 & 10,00 \\
Konsentrat & 30,00 & 30,00 & 30,00 & 30,00 \\
Total & 100,00 & 100,00 & 100,00 & 100,00 \\
\hline
\end{tabular}

Tabel 2. Komposisi Konsentrat

\begin{tabular}{lc}
\hline \multicolumn{1}{c}{ Bahan Penyusun Konsentrat } & BK (\%) \\
\hline Bungkil kelapa & 42,50 \\
Polard & 6,00 \\
Tepung ikan & 1,50 \\
Gaplek & 45,50 \\
NaCl & 2,00 \\
Multi vitamin mineral & 0,50 \\
Molasis & 2,00 \\
Total & 100,00 \\
\hline
\end{tabular}

sebanyak 0,2500 g dan ditambah $25 \mathrm{ml}$ cairan rumen buffer McDougall dengan kondisi $40^{\circ} \mathrm{C}$, selanjutnya diinkubasikan dalam shakerbath dengan suhu $40^{\circ} \mathrm{C}$ selama 4 jam. Cara kerja yang sama dilakukan untuk inkubasi selama 48 jam.

Setelah lama waktu inkubasi yang ditentukan, selanjutnya dikeluarkan dan dipusingkan pada $3500 \mathrm{rpm}$ selama 10 menit. Substrat akan terpisah menjadi endapan di bagian bawah dan supernatan yang bening berada di bagian atas. Supernatan dipakai untuk analisis $\mathrm{N}-\mathrm{NH}_{3}$, VFA Total. Endapan digunakan untuk analisis degradasi bahan kering (BK) dan bahan organik (BO). Kecernaan fermentatif BK dan BO ransum dapat dihitung dengan rumus :

$\operatorname{KCFBO}(\%)=\frac{\text { BO sampel }(\mathrm{g})-[\mathrm{BO} \text { residu }(\mathrm{g})-\mathrm{BO} \text { residu blangko }(\mathrm{g})]}{\text { BO sampel }(\mathrm{g})} \times 100 \%$

\section{Konsentrasi $\mathrm{N}-\mathrm{NH}_{3}$ dan VFA Total}

Kadar $\mathrm{N}-\mathrm{NH}_{3}$ ditentukan dengan metode phenolhypochlorite melalui pembacaan dengan Spectrofotometer menurut Solorzano (1969). Sebanyak $15 \mathrm{ml}$ supernatan dimasukkan ke dalam botol yang sudah berisi 5 tetes asam sulfat pekat, kemudian diencerkan 100 kali. Supernatan yang sudah diencerkan ini diambil sebanyak $5 \mathrm{ml}$, dimasukkan ke dalam tabung spektro yang sudah diisi dengan larutan standar. Kemudian ditambahkan berturut-turut 0,2 ml larutan phenol; o,2 ml larutan Natrium nitroprusside; dan 0,5 ml larutan pengoksidasi. Pembacaan reaksi warna dilakukan 5 menit setelah penambahan larutan pengoksidasi dengan spektrofotometer.

Pengukuran kadar asam lemak atsiri (VFA) Total dilakukan dengan cara penyulingan uap menurut Gene- 
ral Laboratory Procedure (1966). Sebanyak $5 \mathrm{ml}$ supernatan dimasukkan ke dalam tabung khusus kemudian ditambahkan $1 \mathrm{ml} \mathrm{H}_{2} \mathrm{SO}_{4} 15 \%$ lalu ditutup. Tabung dihubungkan dengan labu pendingin dan labu yang berisi air lalu dipanaskan. Hasil destilasi ditampung di dalam erlenmeyer yang berisi $5 \mathrm{ml} \mathrm{NaOH} 0,5 \mathrm{~N}$. Proses destilasi berakhir sampai destilat yang ditampung mencapai volume $\pm 300 \mathrm{ml}$. Tambahkan 1-2 tetes indikator phenolptalin dan dititer dengan $\mathrm{HCl} 0,5 \mathrm{~N}$ sampai terjadi perubahan warna dari merah jambu menjadi tidak berwarna.

VFA Total $=(a-b) \times \mathrm{N} \mathrm{HCl} \times 1000 / 5 \mathrm{mM}$

$\mathrm{a}=\mathrm{ml} \mathrm{HCl}$ yang dibutuhkan untuk titrasi blanko (5 $\mathrm{ml} \mathrm{NaOH})$

$\mathrm{b}=\mathrm{ml} \mathrm{HCl}$ yang dibutuhkan untuk titrasi hasil destilasi

\section{Analisis Data}

Data yang diperoleh pada penelitian ini dianalisis dengan sidik ragam. Apabila terdapat hasil yang berbeda nyata $(\mathrm{P}<0,05)$ antar perlakuan, maka analisis dilanjutkan dengan uji kontras ortogonal pada taraf $5 \%$ (Steel dan Torrie, 1986).

\section{HASIL DAN PEMBAHASAN}

\section{Fermentasi In Vitro}

Fermentasi ransum perlakuan secara in vitro selama 4 jam menunjukkan $\mathrm{pH}$ substrat bervariasi dari 6,41 sampai 6,60 (Tabel 4). Perbedaan komposisi hijauan menyebabkan perbedaan yang tidak nyata $(\mathrm{P}>0,05)$ pada $\mathrm{pH}$ di antara semua perlakuan. $\mathrm{pH}$ rumen merupakan salah satu faktor yang sangat berpengaruh terhadap pertumbuhan populasi dan aktivitas mikroba rumen berada pada kisaran optimum. Menurut Kamra (2005), pH optimum untuk pertumbuhan mikroba rumen adalah 6-6,9, dan pH cairan rumen yang normal adalah 6-7 (Chiba, 2009).

Perbedaan tidak nyata $(\mathrm{P}>0,05)$ juga terjadi pada kadar $\mathrm{N}^{-\mathrm{NH}_{3}}$ substrat semua ransum perlakuan. Produksi $\mathrm{N}-\mathrm{NH}_{3}$ berkorelasi positip dengan kandungan gamal dalam ransum. Peningkatan kandungan gamal sebagai sumber RDP dalam ransum (perlakuan B, C dan D) cenderung meningkatkan produksi $\mathrm{N}^{-\mathrm{NH}_{3}}$ walaupun tidak berpengaruh nyata pada fermentasi in vitro $4 \mathrm{jam}$. Sutardi (1995) menyatakan salah satu pakan yang dapat dijadikan sebagai sumber protein mudah terdegradasi adalah daun gamal (Gliricidia sepium), dimana 66\% dari total protein yang dikandungnya dapat memacu sintesis protein mikroba. Konsentrasi $\mathrm{N}-\mathrm{NH}_{3}$ substrat ransum pada semua perlakuan berada pada kisaran ideal untuk mendukung pertumbuhan bakteri secara optimal yaitu 4-12 mMol (Sutardi, 1979) atau 6-21 mMol (McDonald et al., 2002).
Tabel 4. Produk Fermentasi In Vitro

\begin{tabular}{|c|c|c|c|c|c|}
\hline \multirow{2}{*}{ Peubah } & \multicolumn{4}{|c|}{ Ransum Perlakuan ${ }^{1)}$} & \multirow{2}{*}{ SEM $^{3)}$} \\
\hline & A & $\mathrm{B}$ & $\mathrm{C}$ & $\mathrm{D}$ & \\
\hline \multicolumn{6}{|l|}{ In vitro 4 jam } \\
\hline $\mathrm{pH}$ substrat ransum & $6,41^{\text {a } 2)}$ & $6,58^{a}$ & $6,60^{\mathrm{a}}$ & $6,54^{a}$ & 0,05 \\
\hline Kadar N-NH ${ }_{3}(\mathrm{mMol})$ & $8,78^{a}$ & $9,29^{a}$ & $11,49^{a}$ & $10,71^{\mathrm{a}}$ & 0,78 \\
\hline VFA Total (mMol) & $143,43^{a}$ & $166,40^{\mathrm{a}}$ & $137,82^{\mathrm{a}}$ & $117,91^{\mathrm{a}}$ & 19,27 \\
\hline \multicolumn{6}{|l|}{ In vitro 48jam } \\
\hline $\mathrm{pH}$ substrat ransum & $6,11^{\text {a 2) }}$ & $6,17^{a}$ & $6,10^{\mathrm{a}}$ & $6,02^{a}$ & 0,03 \\
\hline Kadar $\mathrm{N}-\mathrm{NH}_{3}(\mathrm{mMol})$ & $10,88^{a}$ & $11,92^{\mathrm{b}}$ & $12,71^{c}$ & $12,30^{\mathrm{bc}}$ & 0,11 \\
\hline VFA Total (mMol) & $197,03^{a}$ & $142,92^{a}$ & $224,59^{a}$ & $218,46^{a}$ & 25,81 \\
\hline
\end{tabular}

Keterangan :

1) $A=$ rumput gajah $45 \%+$ jerami padi $0 \%+$ gamal $15 \%+$ kaliandra $10 \%+$ konsentrat $30 \%$

$B=$ rumput gajah $30 \%+$ jerami padi $10 \%+$ gamal $20 \%+$ kaliandra $10 \%+$ konsentrat $30 \%$ $C=$ rumput gajah $15 \%+$ jerami padi $20 \%+$ gamal $25 \%+$ kaliandra $10 \%+$ konsentrat $30 \%$ $\mathrm{D}=$ rumput gajah $0 \%$ + jerami padi $30 \%+$ gamal $30 \%+$ kaliandra $10 \%+$ konsentrat $30 \%$ 2) Superskrip yang berbeda pada baris yang sama adalah berbeda nyata $(P<0,05)$

3) SEM = "Standard Error of the Treatment Means"

Konsentrasi VFA Total hasil fermentasi ransum in vitro 4 jam untuk semua perlakuan menunjukkan perbedaan yang tidak nyata $(\mathrm{P}>0,05)$. VFA merupakan sumber energi utama untuk ternak ruminansia (Owen dan Bergen, 1983; Preston dan Leng, 1987), dan jumlahnya bervariasi ( $80-160 \mathrm{mMol}$ ) tergantung jenis ransum dan waktu setelah pemberian pakan (Sutardi, 1979). Pemberian hijauan yang berbeda baik sebagai sumber energi dan sebagai sumber protein dengan komposisi yang berbeda, menghasilkan konsentrasi VFA Total tertinggi pada perlakuan B. Namun demikian, produksi VFA Total pada semua perlakuan sudah mencukupi kebutuhan optimum untuk pertumbuhan dan aktivitas mikroba rumen.

Fermentasi in vitro yang dilakukan selama 48 jam menghasilkan produk seperti tercantum dalam Tabel 4. Derajat keasaman $(\mathrm{pH})$ semua perlakuan bervariasi dari 6,02-6,17 dan semua perlakuan menunjukkan perbedaan yang tidak nyata $(\mathrm{P}>0,05)$. Dibandingkan fermentasi 4 jam, pada fermentasi 48 jam semua $\mathrm{pH}$ ransum menunjukkan angka lebih rendah (Gambar 1). Hal ini disebabkan semakin lama fermentasi terjadi peningkatan konsentrasi VFA sehingga $\mathrm{pH}$ menjadi semakin asam.

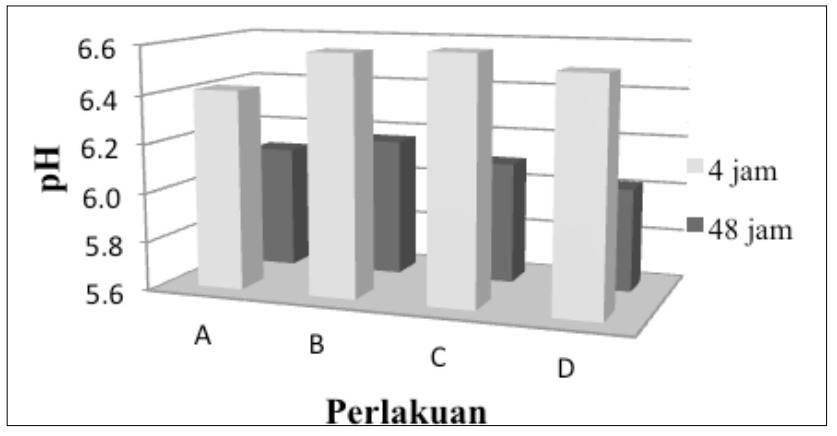

Gambar $1 \mathrm{pH}$ Substrat Ransum Fermentasi in vitro

VFA Total menunjukkan perbedaan yang tidak nyata ( $\mathrm{P}>0,05)$ di antara semua perlakuan. Perlakuan B yang 
sudah mencapai puncak produksi VFA pada fermentasi 4 jam, pada fermentasi 48 jam produksi VFAnya justru paling rendah di antara semua perlakuan. Produksi VFA tertinggi pada fermentasi 48 jam ditunjukkan oleh perlakuan C. Produksi VFA dipengaruhi antara lain oleh jenis dan jumlah hijauan pakan yang diberikan dan juga pH rumen (Peters et al., 1989). Selain itu, semakin lama pakan difermentasi maka semakin tinggi produksi VFA karena mikroba rumen mendapat kesempatan lebih lama untuk mendegradasi pakan. Pada perlakuan B, karena puncak produksi VFA sudah dicapai pada fermentasi 4 jam, maka peningkatan waktu fermentasi tidak mampu meningkatkan produksi VFA lagi. Faktor lain yang mendukung tingginya produksi VFA pada perlakuan $\mathrm{C}$ karena komposisi ransum pada perlakuan $\mathrm{C}$ kemungkinan mengandung karbohidrat terlarut lebih tinggi dan unsur karbon yang terdapat dalam proteinnya sehingga menghasilkan VFA paling tinggi di antara semua perlakuan. Tinggi rendahnya konsentrasi VFA dipengaruhi oleh pakan basal, tipe karbohidrat pakan, bentuk fisik pakan, tingkat konsumsi, frekuensi pakan, dan penggunaan aditif kimia (France dan Dijkstra, 2005).

\section{Kecernaan Fermentatif Bahan Kering dan Bahan Organik In Vitro}

Pengamatan fermentasi rumen secara in vitro selama 4 jam adalah untuk mengevaluasi kemampuan pakan dalam menyediakan substrat bagi mikroba rumen baik untuk pertumbuhan maupun beraktivitas. Berdasarkan data pada Tabel 5 tampak bahwa substrat yang dihasilkan oleh perlakuan $\mathrm{C}$ mengakibatkan aktivitas mikroba tertinggi dilihat dari degradabilitas BK maupun BO.

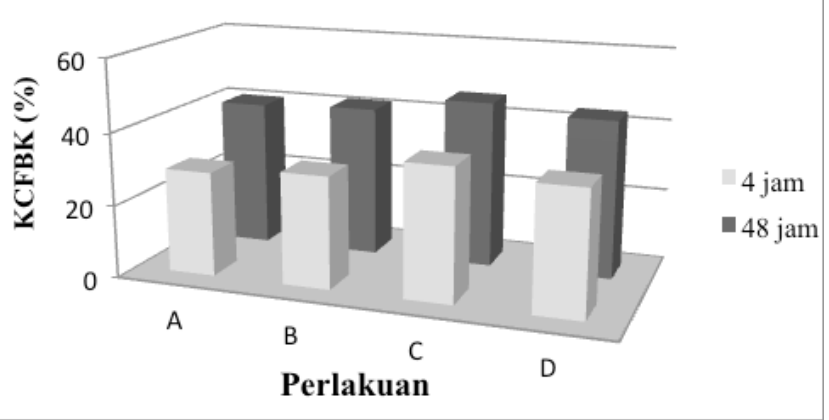

Gambar 2. Koefisien Cerna Fermentatif Bahan Kering in vitro

KCFBK dan KCFBO in vitro tertinggi pada perlakuan C. Walaupun ransum pada perlakuan $\mathrm{C}$ mengandung 20\% jerami padi, dan berkontribusi terhadap kandungan NDF terendah dan lignin kedua tertinggi, namun mampu memberikan KCFBK dan KCFBO tertinggi. Sebagaimana diketahui, lignin merupakan senyawa yang menghambat proses pencernaan. Hal ini disebabkan ransum perlakuan $\mathrm{C}$ mengandung 25\% gamal sebagai sumber RDP sehingga mampu memenuhi kebutuhan mikroba rumen khususnya bakteri akan ketersediaan $\mathrm{N}-\mathrm{NH}_{3}$. Sesuai dengan pernyataan Koster et al. (1996) bahwa penambahan RDP pada level tertentu pada pakan yang mengandung hijauan kualitas rendah, mampu meningkatkan konsumsi BK, BO, KCBO maupun sintesis protein mikroba.

Tabel 5. Kecernaan Fermentatif BK dan BO In Vitro

\begin{tabular}{lccccc}
\hline \multirow{2}{*}{ Peubah } & \multicolumn{4}{c}{ Ransum Perlakuan ${ }^{1)}$} & \multirow{2}{*}{ SEM ${ }^{3)}$} \\
\cline { 2 - 4 } & $\mathrm{A}$ & $\mathrm{B}$ & $\mathrm{C}$ & $\mathrm{D}$ & \\
\hline In vitro 4 jam & & & & & \\
Degradasi BK (\%) & $28,80^{\mathrm{a} 2)}$ & $30,90^{\mathrm{a}}$ & $36,58^{\mathrm{b}}$ & $34,28^{\mathrm{b}}$ & 0,80 \\
Degradasi BO (\%) & $31,89^{\mathrm{a}}$ & $34,44^{\mathrm{b}}$ & $39,74^{\mathrm{c}}$ & $36,10^{\mathrm{b}}$ & 0,57 \\
In vitro 48 jam & & & & & \\
KCFBK (\%) & $40,67^{\mathrm{a}}$ & $41,75^{\mathrm{ab}}$ & $45,97^{\mathrm{c}}$ & $43,62^{\mathrm{b}}$ & 0,50 \\
KCFBO (\%) & $41,29^{\mathrm{a}}$ & $42,46^{\mathrm{a}}$ & $46,87^{\mathrm{b}}$ & $45,03^{\mathrm{b}}$ & 0,49 \\
\hline
\end{tabular}

Keterangan :

1) $A=$ rumput gajah $45 \%+$ jerami padi $0 \%+$ gamal $15 \%+$ kaliandra $10 \%+$ konsentrat $30 \%$

$B=$ rumput gajah $30 \%+$ jerami padi $10 \%+$ gamal $20 \%+$ kaliandra $10 \%+$ konsentrat $30 \%$ $C=$ rumput gajah $15 \%+$ jerami padi $20 \%+$ gamal $25 \%+$ kaliandra $10 \%+$ konsentrat $30 \%$ $\mathrm{D}=$ rumput gajah $0 \%+$ jerami padi $30 \%+$ gamal $30 \%+$ kaliandra $10 \%+$ konsentrat $30 \%$

2) Superskrip yang berbeda pada baris yang sama adalah berbeda nyata $(P<0,05)$

3) SEM = "Standard Error of the Treatment Means"

Lebih tingginya produksi VFA pada fermentasi in vitro 48 jam dibanding fermentasi in vitro 4 jam disebabkan karena mikroba rumen mendapat kesempatan lebih lama mendegradasi pakan dan hal ini memberi keuntungan bagi mikroba rumen sebagai sumber energi yang berdampak pada peningkatan pertumbuhan dan aktivitas mikroba itu sendiri untuk mencerna pakan yang diberikan. Hal ini terlihat pada KCFBK maupun KCFBO ransum fermentasi in vitro 48 jam lebih tinggi dari pada degradasi BK (Gambar 2) dan BO (Gambar 3) ransum yang difermentasi selama 4 jam. Kenyataan ini didukung oleh Putra (2006), bahwa pencernaan pakan secara fermenatif, baik bahan kering (BK) ataupun bahan organik (BO) terdegradasi semakin tinggi sejalan dengan lamanya proses fermentasi berlangsung.

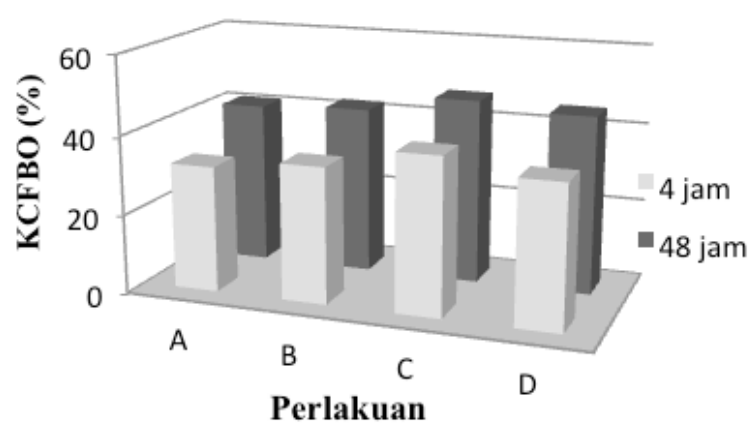

Gambar 3. Koefisien Cerna Fermentatif Bahan Organik in vitro 


\section{KESIMPULAN}

Pada fermentasi ransum secara in vitro baik pada inkubasi 4 jam maupun 48 jam, $\mathrm{pH}$ cairan rumen tetap berada dalam kisaran normal $(6,54-6,79)$. Meningkatnya jumlah gamal sebagai RDP dalam ransum meningkatkan konsentrasi N-NH${ }_{3}$, KCFBK dan KCFBO. Konsentrasi $\mathrm{N}-\mathrm{NH}_{3}$, KCFBK dan KCFBO meningkat pada inkubasi 48 jam dibandingkan inkubasi 4 jam dan tertinggi pada perlakuan $\mathrm{C}$.

\section{UCAPAN TERIMAKASIH}

Terimakasih kami sampaikan kepada Rektor Universitas Udayana melalui Ketua LPPM Unud atas dukungan dana untuk penelitian ini.

\section{DAFTAR PUSTAKA}

Chiba, L.I. 2009. Animal Nutrition Handbook. Second Revision. URL: http://www.ag.auburn.edu/ chibale/ animalnutrition.html diunduh 5 Januari 2011.

France, J. and Dijkstra, J. 2005. Volatile Fatty Acid Productions. In: Quantitative Aspect of Ruminant Digestion and Metabolism. 2nd Ed. CAB. International, Cambridge, USA.

Friss, V. K. 1982. Effect of processing on nutrient content of feeds: Alkali treatment. Handbook of Nutritive Value of Processed Food. Vol. II. Animal Feedstuffs. CRC. Press.

General Laboratory Procedures. 1966. Department of Dairy Science. University of Wisconsin. Madison.

Kamra, D.N. 2005. Rumen microbial ecosystem. Special Section: Microbial Diversity. Current Science, Vol. 89 No. 1:124-135.

Koster, H.H., Cochran, R.C., Titgemeyer, E.C., Vanzant E.S., Abdelgadir, I. and St-Jean, G. 1996. Effect of increas- ing degradable intake protein on intake and digestion of low-quality, tallgrass-prairie forage by beef cows. $J$. Anim. Sci. 1996. 74:2473-2481.

McDonald, P., Edwards, R.A., Greenhalgh, J.F.D., and Morgan, C.A. 2002. Animal Nutrition. 6th Ed. Prentice all, London.

Minson, D.J. and McLeod, M.M. 1972. The In Vitro Technic: its Modification for Estimate Digestibility of Large Numbers of Tropical Pature Technique, Australia.

Owens, F.H. and Bergen, W.G. 1983. Nitrogen metabolism of ruminant animals: Historical perspective, current understanding and future implication. J. Anim. Sci. 57, suppl. 2.

Peters, J.P., Leedle, J.A.Z. and Paulissen, J.B. 1989. Factor affecting the in vitro production of volatile fatty acids by mixed bacterial populations from the bovine rumen. J. Anim. Sci. 67:1593-1602.

Preston, T.R. and Leng, R.A. 1987. Matching Ruminant Production Systems With Available Resources in The Tropics and Sub-tropics. Penambul Books Armidale.

Putra, S. 2006. Pengaruh Suplementasi Agensia Defaunasi Segar dan Waktu Inkubasi Terhadap Degradasi Bahan Kering, Bahan Organik, dan Produks Fermentasi Secra In Vitro. Jurnal Protein Vol. 13. No. 2: 113-123.

Schiere, J.B. and Ibrahim, M.N.M. 1989. Feeding of UreaAmonia Treated Rice Straw. Pudoc Wageningen.

Solorzano Lucia. 1969. Determination of ammonia in natural waters by the phenol hypochlorite method. Limnology and Oceanography. Vol. 14 (5): 799-801. American Society of Limnology and Oceanography.

Steel, R.G.D. and Torrie, J.H. 1986. Priciples and Procedures of Statistic. McGraw-Hill Book Co. Inc., New York.

Sutardi, T. 1979. Ketahanan protein bahan makanan terhadap degradasi oleh mikroba rumen dan manfaatnya bagi peningkatan produktivitas ternak. Pros. Seminar Penelitian Penunjang Peternakan, LPP. Bogor.

Sutardi, T. 1980. Landasan Ilmu Nutrisi Jilid I. Departemen Ilmu Makanan Ternak, Fakultas Peternakan, Institute Pertanian Bogor. 